Full-text Available Online at www.ajol.info and www.bioline.org.br/ja

\title{
Biochemical Investigation on the activities of Acid and Alkaline Phosphatases in two varieties of Carica papaya L. (Pawpaw) during ripening
}

\section{*11AGOREYO, BO; NWEKE, MA}

\author{
Department of Biochemistry, Faculty of Life Sciences, University of Benin, \\ P.M.B. 1154, Benin City, Nigeria. \\ Email: agoreyobo@yahoo.com and amiableonline2006@yahoo.com
}

KEY WORDS: Ripening; Phosphatases; Carica papaya; Agric pawpaw; Local pawpaw

\begin{abstract}
The activities of acid phosphatase and alkaline phosphatase were investigated in two varieties of ripening Carica papaya fruit; Oblong-shaped variety which is also known as 'Agric pawpaw' and Pear-shaped variety which is also known as 'Local pawpaw'. Acid phosphatase activity decreased significantly $(\mathrm{p}<0.01)$ throughout the ripening stages from $0.0186 \pm 0.0006$ to $0.0037 \pm 0.0002 \mu \mathrm{mol} / \mathrm{min} / \mathrm{g}$ fresh weight in the Oblong-shaped variety: 'Agric pawpaw' and from $0.0134 \pm 0.0008$ to $0.0068 \pm 0.0004 \mu \mathrm{mol} / \mathrm{min} / \mathrm{g}$ fresh weight in the Pear-shaped variety: 'Local pawpaw'. Conversely, alkaline phosphatase activity was found to increase significantly $(\mathrm{p}<0.01)$ throughout the ripening stages from $0.0044 \pm 0.0006$ to 0.0135 $\pm 0.0006 \mu \mathrm{mol} / \mathrm{min} / \mathrm{g}$ fresh weight in the Oblong-shaped variety: 'Agric pawpaw' and from $0.0074 \pm 0.0012$ to $0.033 \pm 0.0023 \mu \mathrm{mol} / \mathrm{min} / \mathrm{g}$ fresh weight in the Pear-shaped variety: 'Local pawpaw'. These results suggest that acid phosphatase is the main non-specific phosphatase that is responsible for the production and supply of inorganic phosphate in the unripe stage of Carica papaya fruits, while alkaline phosphatase is responsible for the production and supply of inorganic phosphate in the overripe stage. Acid phosphatase and alkaline phosphatase could be obtained from the unripe and overripe stages of Carica papaya fruits respectively for research purposes, for commercial exploitation and industrial gains. ( JASEM
\end{abstract}

\section{http://dx.doi.org/10.4314/jasem.v18 i2.11}

Introduction: Carica papaya, which is also known as papaya or pawpaw belongs to the family Caricaceae. It is cultivated in most subtropical and tropical countries. C. papaya is an economically important fruit tree, whose fruit is consumed worldwide in the fresh state or used as processed products. (Jaime et al., 2007). Ripe fresh C. papaya fruits are commonly eaten for breakfast and dessert. They are also used in making fruit salads, fresh drinks, ice cream, jelly, jam, marmalade, canned fruit balls or cubes in syrup, crystallized fruit, candies, and paste. Unripe, green fruits are usually pickled or used as vegetables (Geetha and Thirumaran, 2010). The unripe fruit is also a source of papain, a proteolytic enzyme that hydrolyses protein and as such it is used in the preparation of food as meat tenderizer and is of industrial importance. Papain is also used in medications for the treatment of hard tissues on the skin (Hewitt et al., 2000; Chovatia et al., 2010; Seenivasan et al., 2010; Da Silva et al., 2010). Although the fruit of $C$. papaya is edible, the fruit and other parts of the plant are also being used throughout Africa for their medicinal properties
(Afolabi et al., 2011). The fruit has been reported to have antihelminthic activity (Okeniyi et al., 2007).

The fruit of $C$. papaya has different shapes; it may be ovoid-oblong, spherical, cylindrical, and pear-shaped or may have grooves (Zhou et al., 2004; Chen et al., 2007). C. papaya fruit is a climacteric fruit and it exhibits a characteristic rise in ethylene production during ripening; which is accompanied by fruit softening, change in colour, the development of a strong aroma and production of reducing sugar from polysaccharides. Genes that are associated with the development of fruit aroma during ripening have been identified in C. papaya. (Devitt et al., 2006).

Acid phosphatase (EC 3.1.3.2) and alkaline phosphatase (EC 3.1.3.1) are non - specific phosphatases that are grouped as acid or alkaline, based on their optimum $\mathrm{pH}$ below or above $\mathrm{pH} 7$. They are enzymes that catalyse the hydrolysis of phosphate esters to produce inorganic phosphate and their main function in plants is to supply the inorganic phosphate that is required for the 
maintenance of cellular metabolism (Tabaldi et al., 2007; Mishra et al., 2008). Alkaline phosphatase is also employed in molecular biology for the construction of recombinant plasmids because of their ability to cleave $5^{\prime}$ terminal phosphate from DNA fragments (Vemuri et al., 2010).

Inorganic phosphate is an important structural constituent of many biomolecules and phosphorylated intermediate of energy metabolism and it is of critical importance to plant's physiological and biochemical processes (Vance et al., 2003; Vance et al., 2010). Acid phosphatase has been reported to play crucial role in the physiological and biochemical processes that occur in ripening fruits of Musa paradisiaca L. (Agoreyo, 2010). This study was therefore carried out to investigate the activities of acid and alkaline phosphatases in two varieties of $C$. papaya during ripening and to also determine if the fruits could be processed for their enzymes; so that acid and alkaline phosphatases in these fruits could be used for research purposes, for commercial exploitation and industrial gains.

\section{MATERIALS AND METHODS}

Plant Material: Two varieties of $C$. papaya fruits that are oblong and pear shaped and are also known as 'Agric pawpaw' and 'Local pawpaw' respectively, were purchased in their unripe green state from a local Market in Benin City. These fruits were allowed to ripen normally, while samples were collected from them in the unripe, ripe and overripe stages for the analyses of acid and alkaline phosphatases.
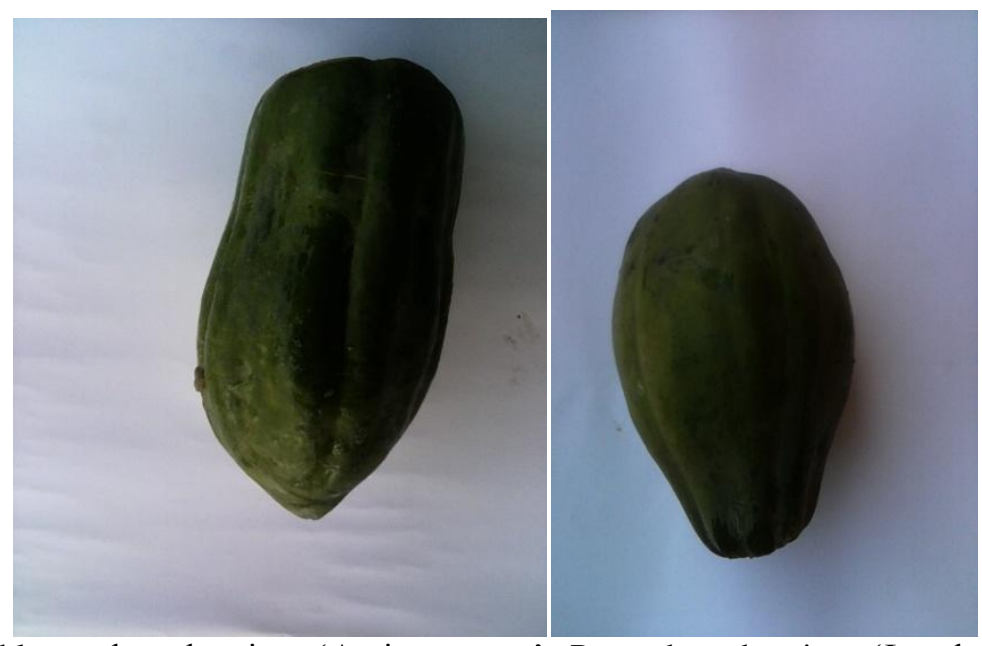

Oblong- shaped variety: 'Agric pawpaw' Pear- shaped variety: 'Local pawpaw'

Figure 1: The two varieties of Carica papaya fruits that were used in this study

Enzyme extraction for non-specific acid phosphatase (EC 3.1.3.2): $5 \mathrm{~g}$ of the fruit of each C. papaya variety were ground in a chilled mortar, with acid washed sand and $20 \mathrm{ml}$ of chilled $50 \mathrm{mM}$ Tris - HCL buffer ( $\mathrm{pH}$ 7.6) containing $1 \mathrm{mM}$ EDTA. The homogenate was filtered through double layers of cheesecloth and centrifuged at $20,000 \mathrm{~g}$ for 20 minutes. The supernatant was used as the crude extract for the enzyme assay (Murray, 1980).

Enzyme Assay For Non-Specific Acid Phosphatase (EC 3.1.3.2): Acid phosphatase activity was assayed by adding $100 \mu \mathrm{l}(0.1 \mathrm{ml})$ of the enzyme extract to $1 \mathrm{ml}$ of $3 \mathrm{mM} \alpha$-Naphthylphosphate in $60 \mathrm{mM}$ Sodium Citrate ( $\mathrm{pH}$ 5.3). The reaction mixture was incubated at $37^{\circ} \mathrm{C}$ for 5 minutes, after which absorbance was read at $405 \mathrm{~nm}$ every minute for another $5 \mathrm{~min}$ in order to determine the $\Delta \mathrm{A} /$ minute (change in *IAGOREYO, BO; NWEKE, MA absorbance per minute). The assay was performed in triplicate and acid phosphatase activity expressed as $\mu$ mol $\alpha$-Naphthol released $\min ^{-1} \mathrm{~g}^{-1}$ fresh weight.

Enzyme Extraction For Non-Specific Alkaline Phosphatase (EC 3.1.3.1): $5 \mathrm{~g}$ of the fruit of each $C$. papaya variety were ground in a chilled mortar, with acid-washed sand and $20 \mathrm{ml}$ of chilled $0.05 \mathrm{M}$ sodium carbonate buffer ( $\mathrm{pH} 10)$. The homogenate was filtered through double layers of cheesecloth and centrifuged at $20,000 \mathrm{~g}$ for 20 minutes. The supernatant was used as the crude extract for the enzyme assay (Agoreyo, 2010).

Enzyme Assay For Non-Specific Alkaline Phosphatase (EC 3.1.3.1): Alkaline phosphatase activity was assayed by adding $0.5 \mathrm{ml}$ of the enzyme extract to $0.5 \mathrm{ml}$ of $3.6 \mathrm{mM}$ Sodium thymolphthalein 
monophophate in $0.2 \mathrm{M}$ 2-Amino-2-methyl-1propanol buffer ( $\mathrm{pH}$ 10.2) containing $1 \mathrm{mM}$ magnesium chloride. The reaction mixture was then incubated at $37^{\circ} \mathrm{C}$ for 10 minutes. The reaction was terminated by the addition of $2.5 \mathrm{ml}$ of $0.1 \mathrm{M}$ sodium hydroxide containing $0.1 \mathrm{M}$ sodium carbonate. The absorbance was read at $590 \mathrm{~nm}$ and the amount of sodium thymolphthalein released was estimated. The assay was performed in triplicate and the alkaline phosphatase activity expressed as $\mu \mathrm{mol}$ sodium thymolphthalein released $\min ^{-1} \mathrm{~g}^{-1}$ fresh weight.

Statistical Analysis : Analysis of variance (ANOVA) was evaluated by the statistical and presentational system software (SPSS). Tukey- Kramer multiple comparison test was employed to determine the statistical differences among the means.

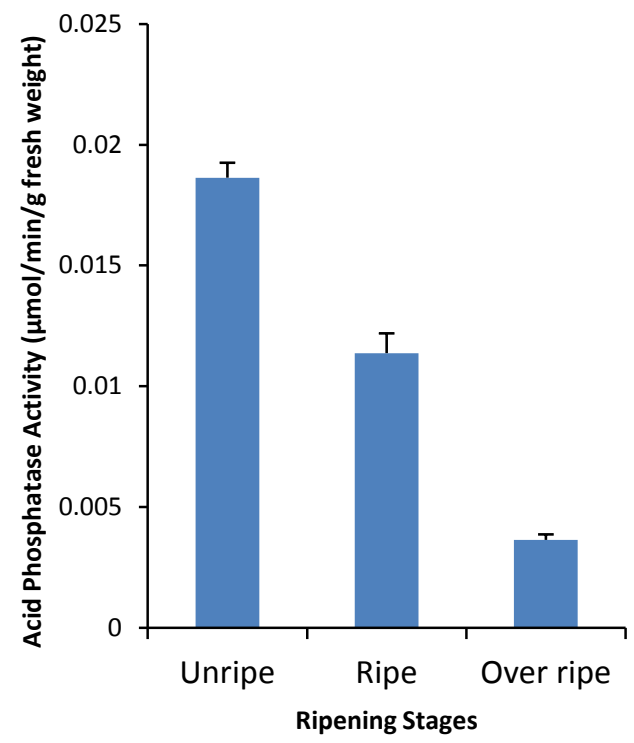

Fig 2a: Acid phosphatase activity of Carica papaya fruit (Oblong- shaped variety: 'Agric pawpaw') at various ripening stages

Acid phosphatase activity of Carica papaya fruit (Pearshaped variety: (Local pawpaw') was also found to decrease significantly $(\mathrm{p}<0.01)$ during ripening. The decrease in activity was $28.83 \%$ (1.4 fold) from the unripe to the ripe stage, while the activity decreased by $49.16 \%$ (2.0 fold) from the unripe to the overripe stage

\section{RESULTS}

Figure 1 shows the two varieties of $C$. papaya that were used in this study. The acid phosphatase activity of $C$. papaya fruit (Oblong-shaped variety: 'Agric pawpaw') showed significant decrease $(\mathrm{p}<0.01)$ during ripening. The activity decreased by $38.98 \%$ (1.6 fold) from the unripe to the ripe stage, while it decreased by $80.47 \%$ (5.1 fold) from the unripe to the overripe stage (Fig. 2a). On the other hand, the alkaline phosphatase activity increased, but not significantly $(\mathrm{p}>0.01)$ from the unripe stage to the ripe stage by $43.97 \%$ (1.8 fold) during ripening. The alkaline phosphatase activity however increased significantly $(\mathrm{p}<0.01)$ from the unripe to the overripe stage by $67.68 \%$ (3.1 fold) from the unripe to the overripe (Fig. 2b).

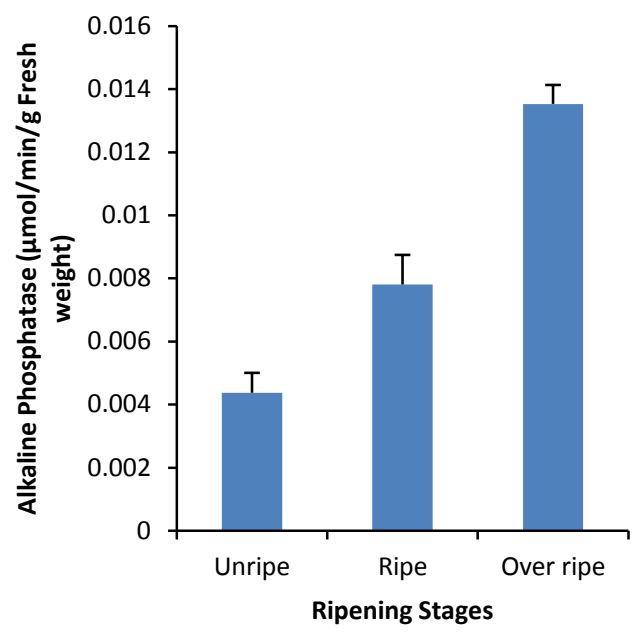

Fig Fig 2b: Alkaline phosphatase activity of Carica papaya fruit (Oblong- shaped variety: 'Agric pawpaw') at various ripening stages

(Fig. 3a). However, alkaline phosphatase activity increased but not significantly $(\mathrm{p}>0.01)$ from the unripe to ripe stage by $42.05 \%$ (1.7 fold). The alkaline phosphatase activity increased significantly by $61.26 \%$ (2.6 fold) from the unripe to the overripe stage (Fig. $3 b)$. 


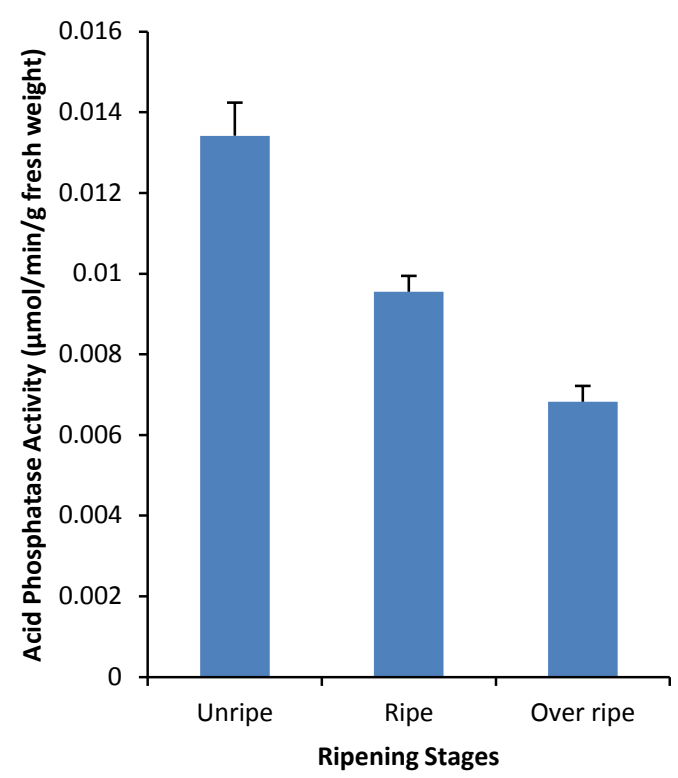

Fig 3a: Acid phosphatase activity of Carica papaya fruit (Pear-shaped variety: 'Local pawpaw') at various ripening stages

\section{DISCUSSION}

The activity of acid phosphatase was found to decrease significantly $(\mathrm{p}<0.01)$ from the unripe to the overripe stage in the two varieties of $C$. papaya that were used in this study. The acid phosphatase activity was highest in the unripe stage of both varieties $(0.0186 \pm 0.0006 \mu \mathrm{mol} / \mathrm{min} / \mathrm{g}$ fresh weight for Oblong-shaped variety: 'Agric pawpaw' and $0.0134 \pm 0.0008 \mu \mathrm{mol} / \mathrm{min} / \mathrm{g}$ fresh weight for Pear-shaped variety: 'Local pawpaw') (Figs 2a \& 3a). The alkaline phosphatase activity however, increased significantly $(p<0.01)$ from the unripe to the overripe stage in two varieties of $C$. papaya. The activity of alkaline phosphatase was highest in the overripe stage in both varieties $((0.0135 \pm$ $0.0006 \mu \mathrm{mol} / \mathrm{min} / \mathrm{g}$ fresh weight for Oblongshaped variety: 'Agric pawpaw' and $0.0330 \pm$ $0.0023 \mu \mathrm{mol} / \mathrm{min} / \mathrm{g}$ fresh weight for Pear-shaped variety: 'Local pawpaw') (Figs $2 \mathrm{~b} \& 3 \mathrm{~b}$ ). The findings of Luthfunnesa et al. (2006), in which they observed an increase in the $\mathrm{pH}$ of $C$. papaya fruit during ripening corroborates with the increase in activity that was observed in alkaline phosphatase and the decrease in activity of acid phoshatase in this study. Agoreyo (2010) also reported that since the activities of acid and alkaline phosphatases are affected by $\mathrm{pH}$; then the non specific phosphatase that is most functional at a particular stage of the developmental process of a

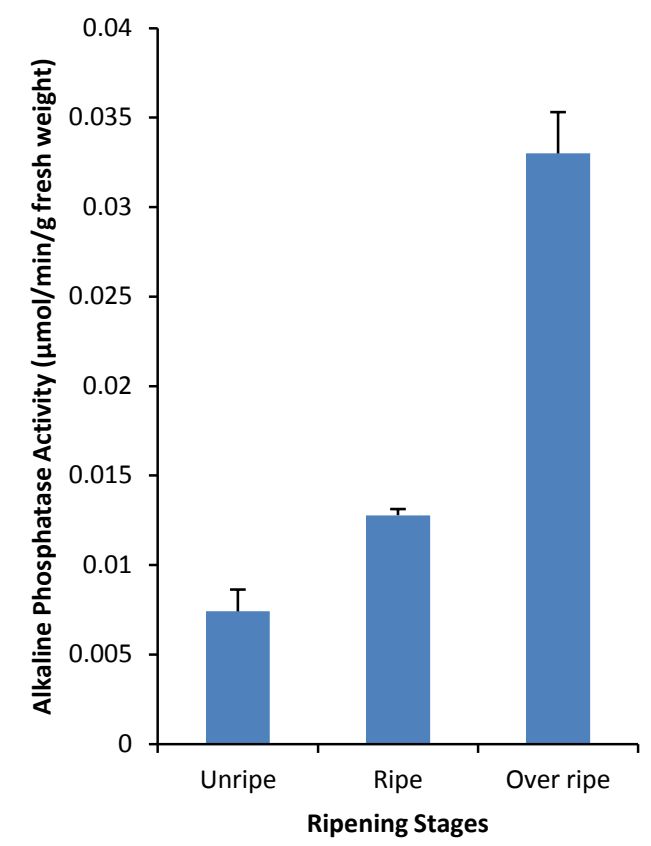

Fig Fig 3b: Alkaline phosphatase activity of Carica papaya fruitfruit (Pear-shaped variety: 'Local pawpaw') at various ripening stages

plant, is determined by the plant's physiological $\mathrm{pH}$ at that period. Increase in acid phosphatase activity and decrease in alkaline phosphatase activity however have been reported in plantain fruits (Musa paradisiaca L.) during ripening , which is due to the increase in acidity of the fruit that results in a low $\mathrm{pH}$. This low $\mathrm{pH}$ favours the optimal activity of acid phosphatase in plantain, during ripening (Agoreyo, 2010). Acid phosphatase has also been reported to function in the maintenance of inorganic phosphate mobility during banana fruit ripening (Turner \& Plaxton, 2001)); while alkaline phosphatase has been reported to be involved in the breakdown and mobilization of starch and sucrose for the biosynthesis of essential oil in lemongrass (Ganjewala et al., 2010).

Comparison of the activities of acid and alkaline phosphatases in the two varieties of $C$. papaya fruits that were used in this study, showed that acid phosphatase was higher in the Oblong-shaped variety: 'Agric pawpaw' than that of Pear-shaped variety: 'Local pawpaw' in all the ripening stages except in the overripe stage (Figs 2a \& 3a). Whereas, the activity of alkaline phosphatase was higher in the Pear-shaped variety: 'Local pawpaw' than that of Oblong-shaped variety: 'Agric pawpaw' in all the ripening stages in this study 
(Figs $2 \mathrm{~b} \& 3 \mathrm{~b}$ ). The fast perishability of C. Papaya fruits and lack of storage facilities in some countries where they are grown, result in a lot of wastage. This wastage could be prevented by obtaining acid phoshatase from the unripe Oblongshaped variety: 'Agric pawpaw' and alkaline phosphatise from the overripe Pear-shaped variety: 'Local pawpaw' for research purposes, for commercial exploitation and industrial gains. Ripening in fruits is associated with respiration, in which sugar phosphates are used. In climacteric fruits such as C. Papaya the rate of respiration is high and the production of the sugar phosphates that are used for respiration requires inorganic phosphate that is produced by acid and alkaline phosphatases from phosphate esters. (Taiz and Zeiger, 2002).

These results suggest that acid phosphatase is the main non-specific phosphatase that is responsible for the production and supply of inorganic phosphate in the unripe stage of Carica papaya fruits, while alkaline phosphatase is responsible for the production and supply of inorganic phosphate in the overripe stage.

\section{REFERENCES}

Afolabi, I.S., Marcus, G.D., Olanrewaju, T.O. and Chizea, V. (2011). Biochemical effect of some food processing methods on the health promoting properties of under-utilized Carica papaya seed. Journal of Natural Products, 4: $17-24$.

Agoreyo, B.O. (2010). Acid phosphatase and alkaline phosphatase activities in ripening fruit of Musa Paradisiaca L. Plant omics Journal. 3:66-69.

Chen, N.J., Manenoi, A. and Paull, R.E. (2007). Papaya postharvest physiology and handling problems and Solutions. Acta Horticulturae, 740: $285-294$.

Chovatia, R.S., Varu, D.K., Delvadia, D.V. and Barad, A.V. (2010). Effect of different varieties and age of fruit on papain production in papaya. Acta Horticulturae, 851: 337 - 342.

Da Silva, C.R., Oliveira, M.B.N., Motta, E.S., De Almeida, G.S., Varanda, L.L., Pádula,

M., Leitão, A.C., and Caldeira - de - Araújo, A. (2010). Genotoxic and cytotoxic safety evaluation of papain (Carica papaya L.) using in vitro assays. Journal of

${ }^{I}$ AGOREYO, BO; NWEKE, MA
Biomedicine and Biotechnology, 2010: 1 8.

Devitt, L.C., Sawbridge, T., Holton, T.A., Mitchelson, K. and Dietzgen, R.G. (2006). Discovery of genes associated with fruit ripening in Carica papaya using expressed sequence tags. Plant Science 170: 356-363.

Geetha, P. and Thirumaran, A.S. (2010). Increasing the shelf - life of papaya through vacuum packing. Acta Horticulturae, 851: 527 - 532.

Ganjewala, D., Nagaraja, C., Nayak, M.R. and Devi, S.A. (2010). Effects of sodium nitroprusside on activity of acid and alkaline invertase in lemongrass (Cymbopogon flexuosus Steud) Wats. International Journal of Plant Biology, 1: 9 -12 .

Hewitt, H.H., Whittle, S., Lopez, S.A., Bailey, E.Y. and Weaver, S.R. (2000). Tropical Uses of Papaya in Chronic Skin Ulcer Therapy in Jamaica. West Indian Medical Journal 49: 32-33.

Jaime, A., Teixeira, da S., Zinia, R., Manoel, T.S. and Paula, F.T. (2007). Papaya (Carica papaya L.) Biology and biotechnology. Tree and Forestry Science and Biotechnology , 1: 47 - 73.

Luthfunnesa, B., Parvez, H., Absar, N., Hague, M.E., Khuda, M.I., Pervinm, M.M., Shahanaz, K. and Hossain, M.I. (2006). Nutrtional Analysis of two local varieties of Papaya (Carica papaya L.) at different Maturation Stages. Pakistan Journal of Biological Sciences 9: 137-140.

Mishra, S. and Dubey, R.S. (2008). Changes in phosphate content and phosphatase activities in rice seedlings exposed to arsenite. Brazilian. Journal of Plant Physiology 20:19 -28.

Murray, D.R. (1980). Some properties of an acid phosphatase isolated from the seed coats of developing pea seeds. Annals of Botany 46: $499-504$.

Okeniyi, J.A., Ogulensi, T.A., Oyelami, O.A. and Adeyemi, L.A. (2007). Effectiveness of dried
342. 
Carica papaya seeds against human intestinal parasitosis: A pilot study. Journal of Medicinal Food, 10: 194-196.

Seenivasan, R., Roopa, L. and Geetha, S. (2010). Investigations on purification, characterization and antimicrobial activity of enzyme papain from Carica papaya Linn. Journal of Pharmacy Research 3: 1092 - 1095.

Tabaldi, L.A., Ruppenthal, R., Cargnelutti, D., Morsch, V.M., Pereira, L.B. and Schetinger, M.R.C. (2007). Effects of metal elements on acid phosphatase activity in cucumber (Cucumis sativus L.) seedlings. Environmental and Experimental Botany, 59:43 - 48.

Taiz, L. and Zeiger, E. (2002). Plant Physiology ( $3^{\text {rd }}$ ed.) Sinauer Associates, Inc., Publishers, Sunderland, Massachusetts, U.S.A. Pp 223 258.

Turner, W.L. and Plaxton, W.C. (2001). Purification and characterization of banana fruit acid phosphatase. Planta, 214: 243 - 249.
Vemuri, P.K., Sunkara, P., Arumalla, C.S.R., Nelapati, D.R. and Lakkoju, A. Characterisation studies of thermostable alkaline phosphatase from various plant seeds. Journal of Applied Biosciences. 36: 2403-2408.

Vance, C.P., Uhde-Stone, C. and Allan, D.L. (2003). Phosphorus acquisition and use: critical adaptations by plants for securing a nonrenewable resource. New Phytologist, 157: 423-447.

Vance, C.P. (2010). Quantitative trait loci, epigenetics, sugars and microRNAs: quaternaries in phosphate acquisition and use. Plant Physiology, 154: 582 - 588.

Zhou, L., Paull, R.E. and Chen, N.J. (2004). Papaya. In: Gross. K.C., Wang, C.Y. and Salveit, M. (eds). The commercial storage of fruits, vegetables and florist and nursery stocks. Agriculture Handbook No 66. USDA - ARS. USA. 